\title{
Survey of basic life support knowledge in security officer of the company along The Daendles Highway
}

\author{
Istiroha, "Ahmad Hasan Basri \\ Department of Nursing, Faculty of Health Science, Gresik University, Gresik, Indonesia
}

Submitted: 28 June 2019 Revised: 3 October 2019 Accepted: 23 October 2019

\begin{abstract}
Giving first aid to traffic accident victims are often not carried out by medical personnel or competent people. The first helper in traffic accidents on the Daendles Highway is the neighboring community and security officers. The purpose of this study was to describe the knowledge level of security officers concerning basic life support in order to give first aid for the accidents along the Daendles Highway of Manyar Subdistrict, Gresik. This study used a descriptive design with a cross-sectional approach. The respondents in this study were 45 security officers of the company, which is spread along the Daendles Highway of Manyar Subdistrict, Gresik, East Java. The sample was taken by purposive sampling. Data were taken using questionnaires then analyzed by univariate techniques with SPSS 16 . The results showed that security with good knowledge was $31.11 \%$, sufficient knowledge was $55.56 \%$, and insufficient knowledge was $13.33 \%$. The characteristic group of respondents who had good knowledge was aged 26-35 years with a working period of 1-5 years and $>5$ years, while the characteristics of the respondents who had insufficient knowledge were aged 36-45 years with a working period of 1-5 years and $>5$ years. Increasing knowledge and skill about basic life support are needed to reduce mortality and increase the life expectancy of victims while waiting for help from medical personnel.
\end{abstract}

KEYWORDS basic life support (BLS); Daendles Highway; East Java; knowledge level; security officer

\section{Introduction}

One of the biggest deaths in the world is caused by traffic accidents. ${ }^{1}$ World Health Organization (WHO) noted 1.35 million people died because of traffic accidents around the world in 2018. ${ }^{2}$ The large number of traffic accident victims cause emergency conditions, so they need rapid help at the scene to prevent morbidity and mortality. Giving appropriate pre-hospital care can reduce the risk of death from traffic accidents. ${ }^{3}$ However, the provision of first aid to victims of traffic accidents is often not carried out by medical personnel or competent people.

Gresik regency is an inter-city and interprovince protocol road in East Java. One of the inter-city protocol roads is Daendles Highway that connects the city of Gresik with the city of Lamongan and its surroundings or inter-city roads that connect between Manyar Subdistrict and Bungah Subdistrict and its surroundings. Gresik police data noted that the Daendles Highway had occurred 522 accidents in 2016 and increased to 596 accidents in 2017. The death around 175 people and 5 people were seriously injured, and 316 victims suffered minor injuries. ${ }^{4}$ The accident occurred at the time of going to school and leaving for work noted 10 times. Then when going home from work with 9 accidents and on Monday noted there were 10 times accidents. ${ }^{5}$

\footnotetext{
*Corresponding author: Istiroha

Department of Nursing, Faculty of Health Science, Gresik University, Jl. Arif Rahman Hakim No. 2B, Kramatandap, Gapurosukolilo, Gresik 61111, Indonesia

E-mail: istiroha08@gmail.com
} 
Victims of accidents can get worse if not treated quickly and can even cause death. ${ }^{1}$ Basic life support (BLS) is an effort that did to maintain the life of someone who is under threat. BLS must be given to victims who experience stop breathing, cardiac arrest, and emergency. Communities should be taught about BLS, especially for workers who are often associated with providing safety assistance. ${ }^{1}$ Security officers in several companies along the protocol road often conduct assistance to victims of traffic accidents or workplace accidents that experience minor injuries or severe injuries and sometimes also help victims themselves with community assistance not accompanied by medical personnel.

Knowledge of first aid, including BLS that did by security officers needs to be known whether using the right techniques or methods. The purpose of this study was to describe the level of security officers knowledge about basic life support along the Daendles Highway of Manyar Subdistrict, Gresik.

\section{Methods}

This study was a cross-sectional descriptive study. Data was taken in April 2019 with the entire population was security at the company located along Daendles Highway, Manyar Subdistrict, Gresik Regency, East Java. Respondents who were physical health, who was on duty, and who were willing to participate were included in this study. However, the security who was off work excluded.

For the process of gathering respondents, researchers worked with companies that provide security services, PT Shelter Nusantara, whose employees are spread across several companies along the Daendles Highway. After assessing the criteria, the researcher explained the purpose of the study to the respondents. If they agreed to participate, they signed the informed consent form and answered the questionnaire. There were 45 respondents included in this study.

The data of this study were collected using a questionnaire modified from Annas ${ }^{6}$ and
Bariqi ${ }^{7}$, which had been used in previous studies. Questionnaires consisted of 20 multiple choice questions, which included the definition of first aid (question no.1), the purpose of help first (questions no. 2 and 3 ), and the first aid method (question no. 4-20). Then the results of the study analyzed using SPSS version 16 .

\section{Results}

The number of samples of this study was 45 respondents. The result shows that the majority of respondents are in the early adult age range (26-23

Table 1. Characteristics of respondents ( $\mathrm{N}=45)$

\begin{tabular}{lcc}
\hline \multicolumn{1}{c}{ Variable } & $\mathbf{n}$ & $\%$ \\
\hline Age & & \\
17-25 years & 7 & 15.6 \\
26-35 years & 23 & 51.1 \\
36-45 years & 13 & 28.9 \\
46-55 years & 2 & 4.4 \\
Sex & & \\
Male & 45 & 100,0 \\
Female & 0 & 0,0 \\
Educational status & & \\
$\quad$ Primary school & 0 & 0.0 \\
Secondary school & 0 & 0.0 \\
High school & 45 & 100.0 \\
University & 0 & 0.0 \\
Work experience & & \\
1-5 years & 26 & 57.8 \\
$\quad$ 5 years & 19 & 42.2 \\
Previous BLS training & & \\
Yes & 0 & 0.0 \\
No & 45 & 100.0 \\
\hline B & &
\end{tabular}

BLS: Basic life support

Table 2. Knowledge level of respondents ( $N=45)$

\begin{tabular}{lcc}
\hline Knowledge level & $\mathbf{n}$ & $\mathbf{\%}$ \\
\hline Good & 14 & 31,1 \\
Sufficient & 25 & 55,6 \\
Insufficient & 6 & 13,3 \\
\hline
\end{tabular}


Table 3. Knowledge level base on respondents characteristic $(N=45)$

\begin{tabular}{|c|c|c|c|}
\hline \multirow{2}{*}{ Variable } & \multicolumn{3}{|c|}{ Knowledge level, n (\%) } \\
\hline & Good & Sufficient & Insufficient \\
\hline \multicolumn{4}{|l|}{ Age } \\
\hline $17-25$ yeras & $0(0)$ & $6(13,3)$ & $1(2,2)$ \\
\hline $26-35$ years & $8(17,8)$ & $13(28,9)$ & $2(4,4)$ \\
\hline $36-45$ years & $6(13,3)$ & $4(8,9)$ & $3(6,7)$ \\
\hline $46-55$ yeras & $0(0)$ & $2(4,4)$ & $0(0)$ \\
\hline \multicolumn{4}{|l|}{ Sex } \\
\hline Male & $14(31,1)$ & $25(55,6)$ & $6(13,3)$ \\
\hline Female & $0(0)$ & $0(0)$ & $0(0)$ \\
\hline \multicolumn{4}{|l|}{ Educational status } \\
\hline Primary school & $0(0)$ & $0(0)$ & $0(0)$ \\
\hline Secondary school & $0(0)$ & $0(0)$ & $0(0)$ \\
\hline High school & $14(31,1)$ & $25(55,6)$ & $6(13,3)$ \\
\hline University & $0(0)$ & $0(0)$ & $0(0)$ \\
\hline \multicolumn{4}{|l|}{ Work experience } \\
\hline $1-5$ years & $7(15,6)$ & $16(35,6)$ & $3(6,7)$ \\
\hline$>5$ years & $7(15,6)$ & $9(20,0)$ & $3(6,7)$ \\
\hline \multicolumn{4}{|l|}{ Previous BLS training } \\
\hline Yes & $0(0)$ & $0(0)$ & $0(0)$ \\
\hline No & $14(31,1)$ & $25(55,6)$ & $6(13,3)$ \\
\hline
\end{tabular}

BLS: Basic life support

years), as many as 23 respondents (51.1\%) and a small percentage are in the age range of the elderly (46-55 years) as many as 2 respondents (4.4\%). All respondents $(100 \%)$ are high school graduates and male sex. More than half of the respondents (57.8\%) had 1-5 years of work experience and all respondents $(100 \%)$ had never attended BLS training before. Data on the characteristics of respondents can be seen in table 1 .

The level of respondents' knowledge about BLS showed that as many as 14 respondents (31.1\%) had good knowledge, 25 respondents $(55.6 \%)$ had sufficient knowledge, and 6 respondents (13.3\%) had insufficient knowledge. Data on the level of knowledge of respondents can be seen in table 2 .

Based on the characteristics of the respondents, it was found that most of the respondent who had suitable and sufficient knowledge level was 26-35 years old. However, most of the respondent who had insufficient knowledge level was 36-45 years old. Based on work experience as a security, there was no difference in the number of respondents who had good knowledge in 1-5 years and $>5$ years of work experience, as well as the number of respondents who had insufficient knowledge. However, respondents with sufficient knowledge had at most 1-5 years of experience. Complete data can be seen in table 3 .

\section{Discussion}

This study shows that most of the respondents had sufficient knowledge level. Differences in characteristics of respondents only in the age range and work experience.

Most respondents were in the age range of 26-35 years, which is the stage of early adulthood. 
They dominated the group of good and sufficient levels of knowledge. All respondents in this study had never received BLS training. This study can reflect that an individual can know about BLS without participating in training, which is through information media access. ${ }^{8}$ The main sources of BLS information can come from schools, universities, or BLS training institutions both from the government and the private sector and also media such as television and the internet. The results of the study in Saudia Arabia, indicate that the most common sources of information about CPR are television and film. This is because the media can reach the broader population to raise awareness about BLS. ${ }^{9}$ Research in Jakarta, Indonesia also shows that the people of Jakarta have a good level of knowledge about BLS with the most information sources from electronic media. ${ }^{10}$

However, the early adult individual has not experienced cognitive changes and is very able to accept or learn new things. ${ }^{11}$ Young age can remember things better than old age. Individuals who are have experienced aging decreased physiological body which will affect the ability to remember information. ${ }^{1,12}$

The result of this study is supported by another study that describes BLS Police knowledge in Depok City. The results of that study showed from 23 police early adulthood $20 \%$ had sufficient knowledge, $17 \%$ had insufficient knowledge, and $13 \%$ had bad knowledge. ${ }^{1}$ However, this study differs from the research of Subki, et al., which describes knowledge in residents in Saudi Arabia. In this study, the age group $<25$ years had better knowledge about BLS than at the age of $\geq 25$ years. ${ }^{8}$ Also, Nugroho's research describes the BLS knowledge level of nurses in the ward. Nurses aged 26-35 years have the lowest level of knowledge. ${ }^{13}$

Other results showed that respondents in the group of 1-5 years of work experience who had sufficient knowledge were 26 people, and good knowledge were 7 people. While in the group of $>$ 5 years of work experience, 9 people had sufficient knowledge and 7 people had good knowledge. The results of this study are not following the theory which explains that a longer experience will increase knowledge and professional skills and develop the ability to make a decision. ${ }^{14}$ The same results show that in the age group 5-10 years no one has good knowledge, enough, less, only got 1 respondent who had inadequate knowledge. ${ }^{1}$

Another research shows that the impact of BLS training on the general public is very good for improving BLS knowledge, attitudes, and skills. ${ }^{15}$ Other studies also show that BLS training provided by the general public can reduce mortality and morbidity. ${ }^{8}$ The results of this study indicate the need to increase BLS training for security personnel to increase knowledge, attitudes, and skills in conducting BLS so that the morbidity and mortality rates for victims of traffic accidents and workplace accidents can decrease.

Security service providers can work together with hospitals or BLS training providers to provide BLS training to their employees so that security capabilities in the field of the rescue of traffic accident victims or work accidents can be increased. Besides, support from the nearest health service institution is also needed. Health service providers can empower security by providing BLS training, so security who already have a BLS certificate can help victims of traffic accidents and workplace accidents before medical personnel arrive at the scene. This can increase the role and motivation of security to participate in helping and saving victims.

The limitation of this study is that the number of samples is small and the area is limited to only Daendles Highway, so the results of the study cannot yet represent the entire population in the Regency of Gresik. Another limitation is the lack of variation in some of the characteristics of respondents, which is level of education, gender, and previous BLS training so that the results of the study do not represent the diversity of characteristics.

\section{Conclusion}

This study shows that most of the security along Daendles Highway had sufficient knowledge level about BLS. Providing BLS training program for 
security by both medical personnel and companies related is needed for improving security knowledge and skill about BLS.

\section{Acknowledgement}

We would like to acknowledge all of the respondents in some companies for their cooperation so this study possible.

\section{Conflict of interest}

There is no conflict of interest.

\section{References}

1. Hutapea EL. An overview of the level of knowledge of traffic police regarding basic life support (BLS) in Depok City [Skripsi]. Depok; Indonesia University. 2012.

2. Hardoko E. WHO: Every 24 seconds one person dies in a traffic accident [internet]. Jakarta: Kompas.com; 2018 [updated 2018 December 7; cited 2019 Juni 25]. Available from: https://internasiona.kompas.com/ read/2018/12/07/13032721/who-tiap-24detik-satu-orang-tewas-akibat-kecelakaan-lalulintas.

3. Miguel GF. Emergency care in the autonomous region of Spain. Improvement in pre-hospital emergency care and welfare coordination SESPAS Espana, Madrid. Journal of Emergency. 2012.

4. S Andi. 600 more traffic accidents occurred in Gresik during 2017 [internet]. Gresik: beritagresik.com; 2017 [updated 2017 December 27; cited 2019 Juni 25]. Available from: https://beritagresik.com/news/ peristiwa/27/12/2017/600-lebih-kecelakaanlalu-lintas-terjadi-di-Gresik-selama-2017.html.

5. Sugiyono. A month, 15-21 people died on the highway in the Gresik region, beware of the following vulnerable locations [internet]. Surabaya: surabaya.tribunnews.com; 2016[updated 2016 Juni 3; cited 2019 Juni 25]. Available from: https://surabaya.tribunnews. com/2016/06/03/sebulan-15-21-orang-tewasdi-jalan-raya-wilayah-Gresik-waspadai-lokasirawan-berikut-ini.

6. Annas DS. Relationship to basic life support (BLS) knowledge with readiness to help PMR member students at Purworejo State Islamic Senior High School [Skripsi]. Gombong; Sekolah Tinggi Ilmu Kesehatan Muhammadiyah. 2016.

7. Bariqi $F$. The effect of simulation-based basic life support training on the level of knowledge helped victims of traffic accidents in Yogyakarta City police [Skripsi]. Yogyakarta; Universitas Muhammadiyah Yogyakarta. 2017.

8. Subki AH, Mortada HH, Alsallum MS, Alattas AT, Almalki $A$, Hindi $M M$, et al. Basic life support knowledge among a nonmedical population In Jeddah, Saudi Arabia: a cross-sectional study. Interact J Med Res. 2018;7(2):1-9.

9. Jarrah $S$, Judeh $M$, AbuRuz ME. Evaluation of public awareness, knowledge and attitudes towards basic life support: a cross-sectional study. BMC Emergency Medicine. 2018; 18: 37.

10. Erawati S. Level of knowledge of the people of Jakarta about Basic Life Support (BLS) in the City Administration of South Jakarta [Skripsi]. Jakarta; Universitas Islam Negeri Syarif Hidayatullah. 2015.

11. Wardani NI, Sarwani D, Masfiah S. Factors related with level of health volunteers knowledge about thalassaemia in sumbang district banyumas regency. Jurnal Kesmasindo. 2014; 6: 194-206.

12. Yusra VD, Machmud R, Yenita. Factors related to the level of knowledge of fertile women about "SADARI" in Nagari Painan. Jurnal Kesehatan Andalas. 2016. 5 (3): 697-704.

13. Nugroho LF. An overview of the level of knowledge of nurses about basic life support (BLS) in the surgical ward in Wates Hospital [Skripsi]. Yogyakarta; STIKES Jenderal Achmad Yani. 2017.

14. Efendi F \& Makhfudli. Community health nursing. Jakarta: Salemba Medika. 2013. 
15. Wijaya WA. The effect of basic life support training on the level of knowledge, skills, attitudes towards basic life support at Gontor
Kediri Islamic Boarding School. IR-Perpustakaan Universitas Airlangga. 